\title{
ПРАШАЊЕТО ЗА РИТАМОТ КАКО СТРАТЕГИЈА ЗА ПЛАНИРАњЕ ВО ВАЛДОРФСКАТА ТЕОРИЈА
}

\section{Кратка содржина}

Во светската педагошка теорија и практика егзистираат повеќе модели на воспитно-образовна работа во предучилишното, основното и средното воспитание и образование. Појавата на овие модели иничирала поинаков пристап во воспитувањето и образованието на децата и учениците, којшто се темели врз влијателните научни достигнувања за развојот на детето во овој период. Со појавата на демократскиот политички плурализам се отвораат можностите кон никнување на т.н. образовен плурализам ${ }^{1}$ кој води кон спектар на образовни алтернативи и можности.

Дел од овој кониепт се идеите на Рудолф Штајнер, преточени во образовна филозофија која според своите карактеристики е сама по себе својствена и оригинална. Валдорфската педагогија претставува еден од ретките модели кој своите педагошки сфаќаъа, идеи и тенденции ги имплементира во многу специифична дидактичко-методска консталачија. Во таа смисла, посебен акцент во овој текст се придава на прашањето за ритамот како основна стратегија во планирање и програмирање на воспитно-образовниот процес.

Клучни зборови: РИТАМ, СТРАТЕГИЈА, ПЛАНИРАЫЕ, ВАЛДОРФСКА ПЕДАГОДИЈА

\section{Вовед}

Суштинските аспекти на валдорфската педагогија се засновани на Штајнеровиот антропозофски духовен поглед на светот кој претставува единствен и специфичен пристап за воспитување и образование на деца. Овој пристап се спроведува во бројни валдорфски градинки и училишта во светот. Сите валдорфски училишта заедно ја сочинуваат најголемата групација од независни приватни училишта во светот, а веројатно и оние со најголем пораст на нови членови.

Значајна суштинска карактеристика на валдорфската педагогија е Штајнеровата категоризација на детскиот развој на три седумгодишни периоди. Всуш-

\footnotetext{
${ }^{1}$ Matijević, M. Pranjić, M. Previšić, V. 1994, Pluralizam u odgoju i školstvu, Zagreb: Katehetski salezijanski centar.
} 
ност, станува збор за идејата за постоење на три „раѓања“, а тие се: физичко раѓање на почетокот на првиот седумгодишен период, раѓање на животната сила во периодот на менување на забите и астрално раѓање кое почнува со пубертетот.

Според Штајнер, во првиот седумгодишен период „волшебната формула на воспитанието“ се примерот и однесувањето. Всушност, овој период почнува со paѓaње на физичкото тело. Малото дете се сфаќа како сетилно битие кое ги набљудува и впива впечатоците од средината.

Вториот седумгодишен период настапува по промената на забите, кога детето може да учи преку авторитетот на воспитувачот од кого се бара да создаде услови каде што детето ќе може да развие добри навики и да добие добар животен ритам кои подоцна ќе му овозможат да ја развие сопствената сила и самостојност.

Третиот седумгодишен период го карактеризира младиот човек кој дури со постигнувањето на полната зрелост ја достигнува онаа зрелост која му овозможува донесување одлуки, развивање на самостојното мислење и ослободување. Во овој период, всушност, сето она што детето го презело од својот пример (тоа се луѓе од неговата околина и историски личности) треба да го докаже при пресудување и при свесното дејствување.

Но, она што е особено значајно за оваа категоризација, всушност, е фактот дека: „поделбата на седумгодишните периоди во антропозофската педагогија не претставува догматска теорија за степените, туку може да се доживеат со интуитивно набљудување на човекот и неговиот ритам“. ${ }^{2}$

Во понатамошната анализа на бројните суштински карактеристики на валдорфската педагогија, неминовно е разгледувањето на Штајнеровите изворни ставови за специфичностите на оваа педагогија. Во таа насока, на едно од своите предавање одржано на 4 октомври 1922 година вели: „Мора да се слуша на поинаков начин од оној кој е вообичаен во врска со воспитувањето, дури и со напредното воспитување, што се укажува во воведот во валдорфската педагогија. Таа педагогија апсолутно не одговара на оние прашања кои ги бара модерното општество, а на прашањата кои се поставуваат се дава привиден одговор од другите системи на воспитување. И каде е насочена целта? Воопшто кон повисокиот култ на расудување, кон тоа расудување толку модерно во сегашноста: ум, интелект, остроумност се членови на максималната распространетост во актуелниот момент. Па така на прашања како што се: што да се прави со детето? или како да му се влее во глава одредена тема?, изненадно се добиваат разумни одговори. И сето тоа се интегрира во прашањата: кои се карактеристиките кои ги сметаме за пожелни кај детето? како да постапиме за да биде тоа онакво какво што сакаме да биде? Сето она што нема значење за најдлабоките аспекти на еволуционата насока на човештвото. Валдорфската педагогија не одговара на такви прашања“. 3

\footnotetext{
${ }^{2}$ Setitz, M. i Hallwachs, U. 1997, Montessori ili Waldorf?: knjiga za roditelje, odgajatelje i pedagoge, Zagreb: Educa, str. 128

${ }^{3}$ Štajner, R. 1996, Pedagoški kurs za mlade: duhovne delatne snage u saživotu starih i mladih generacija, Pančevo: Supra libros, str. 27
} 
Во своите размислувања Штајнер јасно и аргументирано го истакнува ставот дека јазикот на валдорфската педагогија комплетно е поинаков од оној што се користи во традиционалното воспитување. Всушност, специфичноста на оваа педагогија е тоа што таа ,...не е педагошки систем, туку уметност, и тоа уметност за пробудување на она што веќе пулсира во човекот. Во реалноста, таа не тежи да воспитува, туку да буди: прво, да ги пробуди учителите за тие потоа да ги пробудат децата и младите. Навистина се работи за ново будење, по она кога човештвото останало раздвоено, задушено од струјата на постојаната универзална еволуција““ 4

Штајнер, меѓу другото, укажува и на фактот дека особено е важно да се развие едно воспитување кое учи со доживување, кое не се постигнува со речитост, туку само преку една уметност на воспитувањето која се засновува врз вистинското запознавање на човекот.

гија

Антропозофијата - основна карактеристика на валдорфската педаго-

Антропозофијата, всушност, ги отсликува филозофските основи врз кои Рудолф Штајнер, меѓу другото, ја втемелил и валдорфската педгогија. Иако секој пристап за нејзино објаснување се соочува со прилична комплексност, сепак, неопходноста од базичното запознавање со антропозофијата се поставува пред секој обид за разбирање и толкување на оваа педагогија.

Терминот „антропозофија“ доаѓа од грчкиот збор „antropos-sophia“, што во превод значи човекова мудрост. Во голем број книги и предавања Рудолф Штајнер го претставува своето учење кое се нарекува антропозофија. Тој се обидува на еден сестран начин да го направи разбирлив ставот дека нормалниот, секојдневен свет за нас е втемелен на духовниот свет. Преку најразлични феномени, од развојот на билките и историските случувања до човековиот живот пред раѓањето и по смртта, Штајнер ја опишува соработката меѓу физичкиот и духовниот свет.

Според него, антропозофијата нѐ стимулира самите да станеме откривачи и изумители на постоењето преку разновидни помошни средства, но самите треба да одлучиме за она што мислиме дека е потребно. Во моментот кога ќе се сфати дека духовниот свет на повеќе начини влијае на нашето постоење и на светот надвор од нас, тогаш може да се заклучи дека не се работи за исклучива езотерика. Антропозофијата, всушност, означува голема промена во однос на спиритуалната традиција во минатото. Духовноста повеќе не се разбира како затворена во кутија која е надвор од дофат на повеќе луѓе како езотерија.

Всушност, главната промена која антропозофијата ја прави различна и посебна се огледува во „нејзиното свесно настојување да го култивира односот со духовниот свет и односот со физичкиот свет. Во ниту еден момент антропозофијата не трага кон обидите за бегство, напротив, се труди повеќе да ги доведе во контакт еден со друг. Сѐ додека сите оние што се занимаваат со антропозофијата ра-

${ }^{4}$ Ibid, cтp. 27 
ботат на практичната страна на својот живот, не престануваат да ја истражуваат духовноста“".

Антропозофските погледи на Штајнер несомнено се преплетуваат во неговите сфаќања за воспитувањето, за кои во една од своите книги вели: „Антропозофската духовна наука не го разбира воспитувањето како наука, како теоретско сознание, туку како вистинска уметност, како уметност која се занимава со најблагородниот материјал на светот; со самиот човек, со детето кое нам на така прекрасен начин ни ги открива најдлабоките тајни, покажувајќи ни од година на година, би можело да се каже, од недела на недела, што настанува од физиогномијата, од движењата, од сето она што претставува појава во детскиот живот, како настанува духовно, душевно, кое всушност е скриено длабоко во детето како божествен дар од духовните светови“. 6

Според Штајнер, антропозофијата е витален поглед на светот која наоѓа примена во повеќе сфери на модерниот, секојдневен живот, како што се, на пример: антропозофска медицина, валдорфска педагогија, еуритмија - како нова уметност на движењата, а исто така таа иницира нови импулси во архитектурата и уметноста.

Филозофските и теоретските антропозофски форми претставуваат основа на бројните наставни методи кои се применуваат во валдорфските градинки и училишта и се рефлектираат во ставовите на многу валдорфски воспитувачи и наставници, како и во генералното структурирање и ориентирање на валдорфското образование во текот на различните стадиуми на развој.

\section{Прашањето за ритамот како стратегија на планирање}

Валдорфските градинки и училишта се карактеризираат со специфична дидактичко-методска организација. Всушност, слободно може да се каже дека таа е навистина оригинална и единствено својствена за овој педагошки концепт. Практичните решенија поставени околу ова прашање во целост ја олицетворуваат и надополнуваат филозофијата на образованието зададена од Рудолф Штајнер.

Постоењето голем број градинки во целиот свет, поставени во различни културолошки, етнички, религиски и економски развојно детерминирани средини, условуваат поставување на прашањето: дали во сите градинки дидактичко-методската организација се спроведува на ист начин? Во однос на ова прашање, во литературата се истакнати искуства во кои се вели дека суштината на дидактичкометодската организација секаде на ист начин се пренесува во валдорфските градинки. Но, она што е особено значајно е фактот што планот и програмата за работа во овие институции ги поставува принципите на работа и основата на дидактичко-методската организација, без детално определување на конкретен начин на реализација на активностите.

\footnotetext{
${ }^{5} \mathrm{http}: / / \mathrm{www}$.antroposophy.com

6 Štajner, R. 1995, Suvremeni odgoj djece i mladeži, Zagreb: Društvo za waldorfsku pedagogiju Hrvatske, str. 26
} 
Особено радува определбата дека секој воспитувач има слобода во реализацијата на така поставениот план и програма за работа. Оттука, неоспорно е постоењето извесни разлики во практичната реализација во валдорфските градинки во различни земји, кои би можеле да бидат од субјективна природа - воспитувачот или, пак, од објективна природа - општествените детерминанти.

Анализата на дидактичко-методската организација единствено може да создаде слика за вистинската специфичност која е карактеристична исклучиво за валдорфската педагогија.

Најзначаен аспект на оваа проблематика е прашањето на постоењето на ритамот како стратегија на планирањето и што значи, всушност, тоа.

Имено, како што децата секојдневно живеат во ритмички живот на будење и спиење, во градинките, исто така, се работи во регуларен ритам во дневни и неделни активности, како што се музиката и стиховите, следење на движењата и гестикулациите, приказните, практични активности во градината, готвење, шиење и уметнички активности за цртање, моделирање и боење.

Ритамот дозволува децата да се прошират во светот преку играта и потоа сите да се фокусираат на одредена заедничка активност, како што го прават тоа во утринскиот круг или во времето наменето за приказни. Ритамот кај децата носи чувство на постоење и радост, баланс помеѓу играњето од сопствена иницијатива и заедничка работа во останатите активности. Во валдорфската педагогија постои поделба на дневен, неделен и годишен ритам, и тие се инкорпорирани во ритамот на годината со сите свои специфични активности. Токму ритамот им овозможува на децата заштита и помош за избегнување на дисциплински проблеми. Доколку се случи од одредени причини да се наруши дневниот ритам кај децата, тие манифестираат вознемиреност и несигурност од исчекувањето што би можело да се случи.

Суштинската определба на дневниот, неделниот и годишниот ритам претставува основен чекор во анализата на дидактичко-методската организација во валдорфската градинка.

\section{Годишен ритам}

Годишниот ритам се однесува на основната структура на планот и програма за работа во валдорфските градинки кој се темели на смената на годишните времиња и, всушност, сите содржини и активности произлегуваат директно од нив. Главна улога во успешно спроведување на годишниот ритам му се придава на воспитувачот од кого се бара да се соживее со природната и духовната заднина на секој годишен период за да може на соодветен начин да им го пренесе тоа и на децата.

Сето она што се случува за време на секое годишно време одделно во природата, сите промени кои настануваат при тоа, придружени со духовната димензија која се наоѓa во поголемите религиски празници, се доживува преку предвидените содржини зададени во неделниот ритам и планираните активности како 
дел од дневниот ритам. Но, мора да се спомене дека одреден годишен период не се живее само во дидактичко-методска смисла (преку содржините, активностите), туку во тој дух живее и целата градинка, вклучувајќ г ги и сите субјекти кои се дел од неа. Во таа смисла, карактеристиките на годишното време не само што се отсликуваат во игрите, колото, сликањето, моделирањето, преку приказните кои се раскажуваат, туку тоа се пренесува и на закачените слики на sидовите, преку дизајнирање на масата за јадење или свечената маса, аранжирање на вазните со суви дрвца или со расцветани гранчиња итн. Дури и храната ја надополнува целата приказна за даденото годишно време.

Имено, годишниот ритам во валдорфската детска градинка започнува со прославата на жетвата. Од прошетката со своите родители или воспитувачите во парковите децата носат богати плодови од природата кои се карактеристични за есента. Така, во тој период шипките, тиквите, јаболката, оревите, шарените листови и костените се составен дел од активностите на секое дете. Притоа, тие плодови се ставени во функција на декорација на просториите во градинката и, секако, мора да се нагласи неизбежноста од нивната примена како дидактички материјали и средства. Централна активност на децата и воспитувачите во овој период е „работата на селанецот кој ја завршил жетвата и го меле зрното, мелничарот кој прави брашно од зрната и пекарот кој прави леб од брашното“. 7

Во понатамошниот тек на есента, како прв дел од годишниот ритам, се проследуваат спецификите на одредени светци од овој период, како што се, на пример, свети Михаил, свети Мартин. Меѓутоа, тие не се разгледуваат како значаен дел од католичкото празнување, туку се слави нивната големина во смисла на победување на доброто врз злото, како што е примерот кај свети Михаил, или, пак, подготвување за периодот на божикните прослави, каде што преку делото на свети Мартин се слави преминот од темнина кон светлина.

Следува зимата како годишен период и тоа е време на благородните камења, кристалите и џуџињата. Во овој период децата особено се радуваат на самостојно изготвување на џуџињата кои ја отсликуваат работата на елементарните битија во природата. Но, главните активности на сите субјекти во валдорфската градинка се насочени кон прославување на празникот Божик и сѐ се одвива во тој дух.

По долг период, детската градинка повторно ја добива својата шареноликост благодарение на сето она што пролетта го носи сама по себе. Полека сѐ почнува да се разбудува, процутува и оживотворува. Победувањето на долгата зима предизвикува радост кај децата и таа најчесто се изразува преку активноста на коло преку која се приближува чудото на воскреснување, но сѐ уште не станува збор за пренесување на религиски содржини.

Растителниот и животинскиот свет во најголема можна мера се присутни како во занималните така и во градините. Но, во овој период од годишниот ритам децата престојуваат колку што е можно повеќе во природата. Кога децата присуст-

\footnotetext{
${ }^{7}$ Setitz, M. i Hallwachs, U. 1997, Montessori ili Waldorf?: knjiga za roditelje, odgajatelje i pedagoge, Zagreb: Educa, str. 143
} 
вуваат таму, можат непосредно да го доживеат разбудувањето или поточно повторното раѓање на сето она што овенало, згаснало во есента и во зимата.

Сите активности на децата и воспитувачите стануваат подинамични, повесели, како резултат на влијанието на сонцето, небото, зелената трева, музицирањето на птиците итн. Во таква атмосфера и се прославува пролетта.

Потоа следува летото, кое во основа го означува крајот на годината во градинката. Некои од децата се збогуваат сѐ до наесен кога повторно ќе се видат во истата група, а некои, пак, започнуваат едно ново поглавје во животот, односно се подготвуваат за поаѓање во училиште.

Со овој вид организирање на годишниот ритам во валдорфските градинки сметаме дека може да се најде голема поврзаност со еден концепт на позната и веќе применувана (во Република Македонија) форма на планирање, а тоа е тематското планирање. Врз основа на одредени теми, кои, главно, се детерминирани од природните и духовните случувања, произлегуваат суптеми, содржини и активности. Но, постои една мала разлика во тоа што годишниот ритам нема докрај дефинирана строга содржинска структура како што е тоа пример со тематското планиpaњe.

Во годишниот ритам значително се забележува холистичкиот пристап, живеењето во еден дух, со една филозофија која се провлекува од утро до завршетокот на денот, од септември до јуни и во одредена мера ги урива границите на формалната структура карактеристична за тематското планирање.

\section{Неделен ритам}

Неделниот ритам, во основа, го претпоставува специфицирањето на активностите и начинот на реализација на содржините за секоја недела тековно. Теоретски не се посветува големо внимание во однос на ова прашање. Но, она што е особено значајно за нас е истакнување на потребата од зачувување на ритамот во кој живее валдорфската градинка. Пред да се говори за дневниот ритам, неопходно е да се истакне принципот на неделеното планирање за реализација на активностите преку кои ќе се реализираат предвидените содржини.

За да се задржи и негува ритамот кај децата, меѓутоа пренесено на неделно ниво, во валдорфските градинки се планираат уметнички и работни активности (сликање, еуритмија, готвење, цртање, моделирање и сл.) според точно утврден распоред.

Суштината на неделниот ритам се состои токму во сигурноста која децата ја добиваат секоја недела, а произлегува од нивната информираност за тоа што ги очекува. Но, се разбира дека вака поставениот ритам не значи и појава на стереотипи во воспитно-образовната работата во градинките. Основен предуслов за нивно непостоење е шареноликоста на содржините што се реализираат за време на одреден годишен период. 


\section{Дневен ритам}

Концептот за дневен ритам како стратегија на дневното планирање во валдорфските градинки е особено значаен, бидејќ во основа тоа ја претставува дидактичко-методската структура на севкупните активности во текот на еден ден.

Во изобилие на бројни специфичности, дневниот ритам се однесува на следниве карактеристики. Имено, утрата во валдорфските градинки започнуваат со креативни слободни игри и на тој начин детето игра надвор од светот кој постојано го опкружува. Моментите кога воспитувачите и децата ги отстрануваат играчките претставува одлична можност да се научат облиците на грижа и љубов кон сопствените работи. Тие постојано учат да работат со своите раце на корисен начин и притоа да се восхитуваат на убавината на она што го создале. Со перманентно формирање на чувство на топлина и љубов, „валдорфската градинка станува малечко семејство, мал универзум кој однатре е голем““.

Во овие градинки децата заедно со воспитувачите учествуваат во специфични реализации на активностите, како што се, на пример: сечкање зеленчук, приготвување леб и колачи, мелење брашно, чистење простории и мебел, поправање и создавање играчки, шиење кукли и изведување куклени претстави. Оброкот, исто така, се подготвува во соработка со децата и особено се внимава на здравиот начин на исхранување. Во таа насока, најчесто се приготвуваат колачи или леб од органски жита со многу овошје и топла напивка. Времето за секој оброк се доживува како социолошко време, при што децата и воспитувачите заедно ја подготвуваат масата, а со останатите активности продолжуваат откако сите ќе завршат со оброкот.

Децата во овие градинки многу често ја насочуваат својата енергија кон градење, пеење, ископување, готвење, работа во градината, сликање и шиење. Во различни креативни игри тие ги развиваат социјалните вештини, додека, пак, преку многубројни песни, детски рими, еуритмија и народни приказни, тие се хранат со убавините на јазикот. Сите деца учествуваат во ритмичките репетиции во дневни, неделни и сезонски активности и притоа основна цел според валдорфските воспитувачи е децата да научат да ја сакаат работата преку значајни задачи кои ги реализираат.

Иако постои соодветна дидактичко-методска структура на денот, сепак, треба да се потенцира присуството на веќе истакнатата тенденција на холистички пристап во севкупното дејствување. Сите горенаведени активности се реализираат во потполност, но се разбира дека секоја од нив наоѓа примена во различен дневен ритам.

Секој ден во градинката постои одреден ритам - започнува со доаѓањето на децата во 8 часот до нивно заминување во домот во 16 часот.

Во валдорфските градинки многу често се реализираат и дополнителни активности, бидејќи времето за игра со самите себе или со пријателите претставу-

\footnotetext{
${ }^{8} \mathrm{http} / /$ www.openwaldorf.com
} 
ва потреба во оваа возраст која брзо одминува. Поради тоа, постои богата програма со дополнителни активности од областа на уметноста, музиката, еуритмијата или движењето.

\section{Заклучок}

Валдорфската педагогија, односно педагогијата на Рудолф Штајнер, претставува една широка област на проучување, богата со патеки и насоки кои отвораат нови погледи, нови можности за воспитно и образовно дејствување. Постојат бројни извори од кои се добиваат репрезентативни информации за примената на валдорфската педагогија, организирањето и функционирањето на валдорфските градинки и училишта, како и бројни искуства кои произлегуваат од долгогодишната практична примена на оваа програма. Електронските и печатените извори во голема мера го збогатуваат сознанието за оваа педагогија. Но, особено е значаен фактот дека секој извор одделно дава информации од различни аспекти, за различни ситуации, во различни култури, кај различни народи и индивидуи. Всушност, валдорфската педагогија нема идентична примена во секоја институција, нејзината флексибилност овозможува приспособување кон индивидуалните разлики, општествените состојби и културните традиции во секоја земја и секоја институција. Целокупниот живот во одредена градинка или училиште во Германија не може да ги поседува апсолутно истите карактеристики на организација и реализација како, на пример, во одредена градинка или училиште во Хрватска. На овој начин во целост се имплементира идејата на Рудолф Штајнер, кој повикувал на почитување на индивидуалноста кај секоја единка и во секое општество. 


\section{Литература}

Beli, A. (2003), Rudolf Štajner, Beograd: BRIMO

Freunde der Erziehungskunst Rudolf Steiners. (2000), Waldorf pädagogik weltweit, Berlin: Freunde der Erziehungskunst Rudolf Steiners

Carlgren, F. (1990), Odgoj ka slobodi, Zagreb: Društvo za waldorfsku pedagogiju.

Matijević, M. (2001), Alternativne škole, Zagreb: TIPEX

Matijević, M. (1994), Pluralizam u odgoju i školstvu, Zagreb: Katehetski salezijanski centar

Steiner, R. (1979), Die Erziehingsfrage als soziale Frage, Dornach: "bez oznaka"

Steiner, R. (1978), Die Erziehung des Kindes vom Gesichtspunkte der Geisteswissenshaft, Dornach: R. Steiner Verlag

Steiner, R. (1997), Erziehungskunst, Dornach: R. Steiner Verlag

Steiner, R. (1995), Suvremeni odgoj djece i mladeži,Zagreb: Društvo za waldorfsku pedagogiju Hrvatske

Steiner, R. (1995), Odgoj djeteta; sa stanovišta duhovne znanosti, Zagreb: Društvo za waldorfsku pedagogiju Hrvatske

Steiner, R. (1975), Wie erlangt man Erkenntnisse der höheren Welten?, Dornach: R. Steiner Verlag

Štajner, R. (1996), Filosofija slobode, Pančevo: SUPRA LIBROS.

von Heydebrand, C. (Bearbeitet von) (8. Aufl.) (1986), Vom Lehrplan der Freien Waldorfschule, Stuttgart: Verlag Freies Geistesleben.

Župić, S. (1928), Što je euritmija, Beograd: "bez oznaka"

http://www.rudolfsteiner.de

http://www.rudolf-steiner.de

http://www.steinerwaldorf.org 


\section{Alma TASEVSKA \\ Elizabeta TOMEVSKA-ILIEVSKA \\ Elena RIZOVA \\ THE ISSUE OF RHYTHM AS A STRATEGY IN THE PLANNING OF THE WALDORF PEDAGOGY}

\section{Summary}

In the world, in the pedagogical theory and practice, there exist several models of educational work in the pre-school, elementary school and high school education. The appearance of such models has initiated a different approach to the educational aspect of the children and pupils, which is based on the influential scientific achievements regarding the development of the child in this period. The Democratic Political pluralism opened up new possibilities towards instigating the so-called "educational pluralism ", , which leads towards a spectrum of educational alternative possibilities.

A part of this concept concerns the ideas of Rudolf Steiner, described through the educational philosophy with its characteristics as being original. The Waldorf pedagogy represents one part of the rare models whose pedagogical foundations, ideas and tendencies are implemented in quite a specific didactic-methodic constellation. In such a context, special emphasis in this text is put on the issue of rhythm as an elementary strategy in the planning and programming of the educational process.

Keywords: RHYTHM, STRATEGY, PLANNING, WALDORF PEDAGOGY

\footnotetext{
${ }^{9}$ Matijević, M., Pranjić, M., Previšić, V. 1994. Pluralizam u odgoju i školstvu, Zagreb: Katehetski salezijanski centar.
} 